\title{
State III to Stage V Renal Dysfunction \& Significant Restoration to Normal EGFR by Novel ACE Inhibitors-A Retrospective Study
}

\author{
Vinod C Tawar* \\ Division of Family Medicine, Manchanda Medical Clini, Canada
}

Submission: March 11, 2017; Published: April 19, 2017

*Corresponding author: Vinod C Tawar, Department of Pharmaceuticals, Manchanda Medical Clini, Canada, Email: tawar.vinod@yahoo.com

\begin{abstract}
This study has been based on the improvements observed in predominantly diabetic patients with EGFR falling below normal, leading to stage III and stage IV renal damage. The study consisted of a review of 82 patients' clinical records.

Approximately 27\% of the patients had demonstrated falling EGFR and were started on Perindopril 8mg or Trandolopril 2-4mg per day. The duration of treatment needed to restore to normal EGFR varied from eight to sixteen weeks depending on the extent of dysfunction $(E G F R>40)$. The population consisted of male and female patients mainly of South Asian origin. Perindopril has shown to be beneficial in patients with EGFR of over 40 and Trandolopril $4 \mathrm{mg}$ dose has been useful in patients with stage IV cases. The findings have encouraged me to initiate diabetic patients with the above mentioned ACEI for prevention of renal dysfunction.
\end{abstract}

\section{Introduction}

In early 2000, I had encountered a patient with declining EGFR, below normal value in addition to having uncontrolled blood pressure, (he was on Enalapril 5mg od). I had increased his Enalapril to $20 \mathrm{mg}$ once per day for six to eight weeks and observed a normalized EGFR with improved blood pressure control without an increase in serum potassium or creatinine. This experience inspired me to my recent trial treatment of Perindopril and Trandolopril. In addition, Olmesartan was tried and observed to be not as beneficial in renal repairment.

\section{Past Investigations}

Heerspink et al. [1] described an analyses of the ADVANCE trial and outlined a high risk of cardiovascular disease in individuals with diabetes and chronic kidney disease. The authors assessed the effects of ACEI in patients with type 2 diabetes according to baseline chronic kidney disease. Blood pressure reduction prevents cardiovascular events in high risk patients [2]. In diabetic patients, ACE inhibitors and diuretics have been most commonly used for their risk reduction of renal and cardiovascular events [3].

Earlier in 2008, Sue [4] described a reduction of renal disease in diabetic patients with a treatment consisting of Perindopril/ Indapamide. The main results from the blood pressure part of the ADVANCE trial showed a reduction in major events including death with Perindopril/Indapamide compared to placebo group among diabetic patients. The researchers explained the blood pressure being a key determinant of nephropathy.

Ghiadani [5] in July 2010 provided further correction of ADVANCE trial. He stated that a blood pressure reduction and glucose lowering were effective in reducing morbidity and mortality. In the trial, further evidence was obtained of intensive glycemic control with Gliclazide MR in combination with Perindopril/Indapamide.

Lewis et al. [6] outlined a study on the effect of Captopril on renal protection properties independent of it's effect on blood pressure in diabetic nephropathy.

Zhang et al. [7] in Prisma Compliant Network Meta Analysis showed a superiority of Trandolopril among ACEI in controlling the blood pressure.

Further study by Li et al. [8] in 2015 demonstrated an effective Ace inhibitor action of Trandolopril. Svenstorm et al. [9] in March 2015 also showed equal effects of different ACEI on mortality in systolic heart failure.

Hosseini \& Addullahi [10] in 2013 had demonstrated a role of Trandolopril in diabetic nephropathy.

\section{Method}

In my practice of approximately 5 to 6 thousand patients, approximately $10 \%$ are diabetic. The factors contributing 
to renal dysfunction have been identified as family history, lifestyles, obesity, alcohol addiction, uncontrolled blood pressure etc. A few patients with renal dysfunction have demonstrated at the earliest stage that blood pressure control in addition to glycemic control being a challenging issue. The current study of approximately twelve months duration, of patients on ACEI trial has been based on monitoring of $\mathrm{Hb} \mathrm{A} 1 \mathrm{C}, \mathrm{Na}, \mathrm{K}$, Urea, Creatinine and EGFR.

Patients with EGFR lower than 59 were started on either $8 \mathrm{mg}$ of Perindopril/day or 2-4mg of Trandolopril in resistant cases. The increase in EGFR was observed within four to sixteen weeks. e.g. patients with EGFR of 40-42 demonstrated normalization in twelve to sixteen weeks. In cases of EGFR less than 40, Trandolopril treatment had shown beneficial effects while being resistant to Perindopril. In cases of EGFR lower than
20, the extent of increases were multi-factorial e.g. glycemic control or the degree of anemia of chronic disease. The patients were in the age group of 35 to 90 years and gender distribution of male to female was 1.5 to 0.5 .

\section{Observations}

The laboratory data of the patients from pre-treatment level to current stage are listed on the table.

\section{Conclusion}

a. Improvement in renal functions on sustained basis was observed in STAGE III impairment in diabetics with a 30\% decline of EGFR (from normal) to a restoration value of 59 in six to sixteen weeks with a treatment of Perindopril 8 $\mathrm{mg} /$ day. During this time period blood pressure control was optimal Table 1.

Table 1: Stage I to III impairment.

\begin{tabular}{|c|c|c|c|c|c|c|c|c|c|c|}
\hline & Patient & Age & Med & DX & Pre TX & Post TX & HbA1C & DUR & Serum & $\mathrm{K} / \mathrm{CR}$ \\
\hline 1 & A A & M 62 & $\mathrm{P}$ & $\mathrm{D} / \mathrm{V} / \mathrm{CKD}$ & 57 & 86 & 8 & $10 \mathrm{mos}$ & & $\mathrm{N}$ \\
\hline 2 & G K & F 62 & $\mathrm{P}$ & DM IHD & 58 & 72 & 8.6 & $8 \mathrm{mos}$ & & $\mathrm{N}$ \\
\hline 3 & R C & M 67 & $\mathrm{P}$ & DM CKD & 52 & 58 & 6.7 & $5 \mathrm{mos}$ & & $\mathrm{N}$ \\
\hline 4 & $\mathrm{~N} \mathrm{~J}$ & M 79 & $\mathrm{~T}$ & DM CKD & 44 & 46 & 6.8 & $6 \mathrm{wks}$ & & $\mathrm{N}$ \\
\hline 5 & $\mathrm{~N} \mathrm{~J}$ & F 62 & & DM CKD & 55 & 61 & 7.1 & 6 wks & & $\mathrm{N}$ \\
\hline 6 & P S & M81 & $\mathrm{T}$ & DM CKD & 57 & 60 & 6.7 & $10 \mathrm{mos}$ & & 5.5 \\
\hline 7 & A D & M 79 & $\mathrm{~T}$ & DM CKD & 36 & $29 / 30$ & 6.2 & 6 wks & & 5.2 \\
\hline 8 & G G & F 67 & OLM & DM CKD & 16 & 17 & 7.4 & $18 \mathrm{mos}$ & & $\mathrm{N}$ \\
\hline 9 & $\mathrm{CM}$ & F 73 & $\mathrm{P}$ & DM CKD & 47 & 65 & 5.9 & $16 \mathrm{mos}$ & & $\mathrm{N}$ \\
\hline 10 & $\mathrm{CN}$ & M79 & $P$ & $\begin{array}{c}\text { DM CKD } \\
\text { HTN }\end{array}$ & 33 & 50 & 7.3 & d wks & & $\mathrm{N}$ \\
\hline 11 & C M & F 69 & $\mathrm{P}$ & $\begin{array}{c}\text { CKD } \\
\text { CKD } / D / V \\
\end{array}$ & 56 & 61 & 6.8 & $22 \mathrm{mos}$ & & $\mathrm{N}$ \\
\hline 12 & $\mathrm{HA}$ & F 60 & $\mathrm{P}$ & $\begin{array}{l}\text { CKDCKD } \\
\text { DM }\end{array}$ & 69 & 92 & 6.6 & $1 \mathrm{yr}$ & $\mathrm{N}$ & \\
\hline 13 & K S & F 59 & $\mathrm{P}$ & $\begin{array}{l}\text { CKD IHD } \\
\text { DM }\end{array}$ & 39 & 30 & 7.6 & $1 \mathrm{yr}$ & $\mathrm{N}$ & Cr 161 \\
\hline 14 & $\mathrm{C} \mathrm{C}$ & M 66 & $\mathrm{P}$ & CKD D/A & $\mathrm{J} 2$ & 63 & $8.1-6.4$ & $8 \mathrm{mos}$ & 5.2 & Cr 6J2. 7 \\
\hline 15 & $\mathrm{~K} \mathrm{~s}$ & r 04 & $\mathrm{P}$ & CKDDM & 53 & 59 & 13.1-6.3 & $8 \mathrm{mos}$ & $\mathrm{N}$ & $\mathrm{Cr} 93 \mathrm{~N}$ \\
\hline 16 & D A & F 63 & $\mathrm{P}$ & CKDDM & 52 & 60 & $8.7-7.7$ & $16 \mathrm{mos}$ & 5.2 & $\mathrm{Cr} 94 \mathrm{~N}$ \\
\hline 17 & M M & M 78 & $\mathrm{TP}$ & $\begin{array}{l}\text { CKD IHD } \\
\text { DM }\end{array}$ & 36 & $\mathrm{~J} 0$ & 9.J-8.2 & $8 \mathrm{mos}$ & $\mathrm{N}$ & \\
\hline 18 & D S & F21 & $\mathrm{P}$ & DN/CKD & 42 & 46 & 6.5 & $2 \mathrm{mos}$ & $\mathrm{N}$ & Cr 103 \\
\hline 19 & S R & M 60 & $\mathrm{TP}$ & CKD & 54 & 64 & & $1 \mathrm{yr}$ & $\mathrm{N}$ & $\begin{array}{c}\text { N/UR AC } \\
\text { high }\end{array}$ \\
\hline 20 & SB & M62 & $\mathrm{P}$ & CKD D/a & $4 d$ & Jo & 9.6 & $4 \mathrm{mos}$ & $\mathrm{N}$ & Cr 144 \\
\hline 21 & SN & F82 & $\mathrm{P}$ & DM CKD & 59 & 75 & 6.2 & $2 \mathrm{mos}$ & 5.4 & \\
\hline
\end{tabular}

b. While Perindopril or Trandolopril treatments offered similar results, some patients were resistant to Perindopril treatment at the level of minimal decline in EGFR.

c. In stage IV renal dysfunction there was a better success with Trandolopril treatment, however a 70 year old female diabetic with EGFR of 35 at the onset has shown an increase of EGFR to 49 with Perindopril 8mg over twelve months and not Trandolopril.

d. Once restoration of EGFR to normal value, the improvements remained sustained with the continuation of ACEI Table 2. 
Table 2: Accidental discontinuation of perindopril.

\begin{tabular}{|c|c|c|c|c|c|c|c|c|c|c|c|}
\hline & Patient & Age & Med & Dx & $\begin{array}{c}\text { Pre TX } \\
\text { EGFR }\end{array}$ & $\begin{array}{c}\text { Post Tx } \\
\text { EGFR }\end{array}$ & HbA 1C & DUR & Serum & $\mathrm{K} / \mathrm{CR}$ & \\
\hline 1 & SB & M 65 & P8 & DM CKD & 5 & 22 & 8.3 & $8 w k s$ & & $\mathrm{~N}$ & \\
\hline $\begin{array}{l}\text { EGFR } \\
\text { dropped } \\
\text { from } \\
5.2-5 \text { in } 2 \\
\text { weeks }\end{array}$ & & & & & & & & & & & \\
\hline 2 & VT & M73 & P8 & DM CKD & 104 & 66 & 8 & $1 \mathrm{yr}$ & & $\mathrm{N}$ & $\mathrm{D} / \mathrm{c} 5 \mathrm{D}$ \\
\hline
\end{tabular}

P: Perindophil; T: Trandolopril; N: Normal; C: Creatinine; UR AC: Urid Acid

Table 3: Stage IV and Stage V impairment.

\begin{tabular}{|c|c|c|c|c|c|c|c|c|c|c|}
\hline & Patient & Age & Med & Dx & $\begin{array}{c}\text { Pre TX } \\
\text { EGFR }\end{array}$ & $\begin{array}{c}\text { Post Tx } \\
\text { EGFR }\end{array}$ & HbA 1C & DUR & $\begin{array}{l}\text { Serum } \\
\text { CR }\end{array}$ & $\mathbf{K}$ \\
\hline 1 & KS & 62 & P-I & $\begin{array}{l}\text { DM IHD } \\
\text { CKD }\end{array}$ & 12 & 24 & 7.5 & 8wks & $\mathrm{N}$ & $\mathrm{N}$ \\
\hline 2 & SB & 66 & P-I & DM CKD & 5 & 22 & 8.2 & $8 \mathrm{WKS}$ & $\mathrm{N}$ & $\mathrm{N}$ \\
\hline 2 & R G & 69 & P-I & DM CKD & 12 & 20 & 6.9 & $1 \mathrm{yr}$ & $\mathrm{N}$ & 5.7 \\
\hline
\end{tabular}

e. Among patients with extreme stage IV dysfunction e.g. EGFR 12-20, the progression to further decline remained curtailed by Trandolopril $4 \mathrm{mg}$ /day treatment Table 3 .

f. During the course of treatment with either Perindopril $8 \mathrm{mg}$ or Trandolopril $4 \mathrm{mg}$ serum creatinine and potassium remained in normal range.

Table 4: CKD Stages.

\begin{tabular}{|c|c|c|c|}
\hline Stage & EGFR & Description & Treatment Stage \\
\hline I & $90+$ & $\begin{array}{c}\text { Normal kidney function, minimal } \\
\text { structural damage or genetic trait } \\
\text { pointing to kidney disease }\end{array}$ & BP Controlled \\
\hline II & $60-89$ & Mildly reduced kidney function & Control of BP and DM \\
\hline IIIA & $45-59$ & $\begin{array}{c}\text { Moderately reduced kidney } \\
\text { function }\end{array}$ & ACEI inhibitors BP DM \\
\hline IIIB & $30-44$ & Same as above & Same as above \\
\hline IV & $45-29$ & Severely reduced kidney function- \\
ESRD & ACEI \\
\hline V & $1-15$ & Same as above & Dialysis \\
\hline
\end{tabular}

h. A 75 year old male diabetic with stage IV renal disease showed improvement with Olmesartan (EGFR 12-20) and not Perindoprl or Trandolopril.

i. The study consisted of predominantly diabetic patients however two patients with hypertension (STAGE IV ) and gout (STAGE III) showed renal dysfunction as well, however, in the latter case a normal EGFR has been restored with Perindopril.

j. Recently, a female patient, 75 yrs old with early stage diabetes and STAGE III dysfunction (EGFR 36) had improvement of EGFR to 46 with Perindopril in eight weeks. After discontinuation of ATACAND 16mg however, suffered from persistent cough from ACEI. The end result was that EGFR had declined back to 36, once the ARB was restarted. g. Patients with anemia of chronic disease $(\mathrm{Hb}$ value less than 90) showed a reduction in EGFR in spite of the optimal dose of ACE inhibitor. However an increase was observed once the value of HbA1C had improved to more than 100 Table 4.

\section{Applications}

The restoration of renal disease to a normal EGFR value has not only prevented a deterioration to ESRD, anemia, future cardiac events but also rendered the patients being able to seek treatments with newer medications which otherwise would not be accessible due to dysfunctions e.g. SGLT inhibitors. In addition the incidences of patients requiring dialysis have been drastically reduced.

\section{References}

1. Heerspink HJ, Ninomiya T, Perkovic V, Woodward M, Zoungas S, et al. (2010) Effects of a fixed combination of perindopril and indapamide in patients with type 2 diabetes and chronic kidney disease. Euro Heart J 31(23): 2888-2896.

2. Medscape Multispeciality (2016) Perindopril. Drug \& Diseases USA. 
3. Medscape multispeciality (2016) Indapemide in T2 Diabetes and CKD. Drug \& Diseases USA.

4. Misset B, Nakache D, Vesin A, Darmon M, Garrouste-Orgeas M, et al. (2008) Reliability of diagnostic coding in intensive care patients. Crit Care 12(4): R95.

5. Ghiadone L (2010) Management of high blood pressure in type 2diabetes: perindopeil/indapamide fixed dose combination and the ADVANCE trial. Expert Opin Pharmaco 11(10): 1647-1657.

6. Lewis EJ, Hunsicker LG, Bain RP, Rohde RD (1993) The Effect of Angiotenusin-converting enzyme inhibitor in diabetic nephropathy. N Engl J Med 329(20): 1456-1462.
7. Sun W, Zhang H, Guo J, Zhang X, Zhang L, et al. (2016) Comparison of the efficacy and safety of different ACE inhibitors in patients with chronic heart failure. A Prisma-compliant Network Meta Analysis. Medicine (Baltimore) 95(6): e2554.

8. Li x, et al. (2015) Pharmacokinetics, Pharmacodynamics and Tolerability of single and multi doses of Trandolopril. An Effective ACE inhibitors in Healthy Chinese Students. Eur J Drug Metabolism PHARMACO Kinet.

9. Svanström H, Pasternak B, Melbye M, Hviid A (2015) Use of different types of angiotensin converting enzyme inhibitors and mortality in systolic heart failure. Inl J Cardiol 182: 90-96.

10. Hosseani A, Abdullahi M (2013) Ovid Med Cell. Langev pp. 168039.

\section{Your next submission with Juniper Publishers will reach you the below assets}

- Quality Editorial service

- Swift Peer Review

- Reprints availability

- E-prints Service

- Manuscript Podcast for convenient understanding

- Global attainment for your research

- Manuscript accessibility in different formats ( Pdf, E-pub, Full Text, Audio)

- Unceasing customer service

Track the below URL for one-step submission https://juniperpublishers.com/online-submission.php 